\title{
ANALISIS PENDISTRIBUSIAN LABA DALAM AKUNTANSI SYARIAH UNTUK MENCAPAI PRINSIP KEADILAN PADA PT. BANK PANIN DUBAI SYARIAH Tbk
}

\author{
Sahrullah \\ Universitas Muhammadiyah Makassar \\ Email: sahrul@unismuh.ac.id \\ Wahyuni \\ Universitas Muhammadiyah Makassar \\ Email: wahyunirahman12@gmail.com
}

\begin{abstract}
This study aims to determine the distribution of profits in Islamic accounting at the Panin Dubai Syariah Bank. This study uses a quantitative descriptive analysis method in which company data used are financial statements and an explanation of the desired data in this study is the 2016-2018 financial statements. The results showed that the didtribution of profits to companies that apply Islamic accounting has been distributed proportionally where the profits are nit only distributed to capital owners, but the distribution is also carried out to customers, employees, alms, and general reserves. Although for 2017-2018 there is no distribution of zakat. Implementation of the fair value of the distribution of profits has reached fair value in accordance with company policy rules. Although it has not been fully realized according to Islamic rules because the distribution of shareholders' profit is greater than that of customers.
\end{abstract}

Keywords: Profit and Justice Distribution

\begin{abstract}
Abstrak
Penelitian ini bertujuan untuk mengetahui pendistribusian laba dalam akuntansi syariah pada Bank Panin Dubai Syariah. Penelitian ini menggunakan metode analisis deskriptif kuantitatif dimana data-data perusahaan yang digunakan adalah laporan keuangan dan penjelasan mengenai data yang diinginkan dalam penelitian ini adalah laporan keuangan tahun 2016-2018. Hasil penelitian menunjukkan bahwa pendistribusian laba pada perusahaan yang menerapkan akuntansi syariah telah terdistribusi secara proporsional dimana mendistribusikan labanya tidak hanya kepada pemilik modal saja tetapi pendistribusian juga dilakukan kepada nasabah, karyawan, zakat, dan cadangan umum. walaupun untuk tahun 2017-2018 tidak ada pendistribusian zakat. Implementasi nilai keadilan pendistribusian laba sudah mencapai nilai keadilan sesuai dengan aturan kebijakan perusahaan Walaupun belum terwujud secara penuh menurut aturan islam karena pembagian laba kepemegang saham lebih besar dibandingkan ke nasabah.
\end{abstract}

Kata Kunci: Pendistribusian Laba dan Keadilan 
Invoice: Jurnal Ilmu Akuntansi

p-ISSN: 2714-6359 e-ISSN: 2714-6340

Vol.2 Nomor 2 September 2020

\section{PENDAhuluan}

Konsep pendistribusian laba untuk pemilik modal banyak dikritik oleh para ilmuan bidang akuntansi yang bersifat egoistik kapitalistik karena yang menikmati laba hanya pemilik modal (capital). padahal Modal merupakan hanya salah satu faktor penunjang dalam sebuah produktivitas. Selain modal ada faktor produktivitas yang mempunyai peran sentral dalam sebuah aktivitas bisnis yaitu faktor sumber daya manusia dan sumber daya alam. Dalam islam sejatinya laba didistribusikan sesuai dengan besaran kontribusinya (Surepno:2017)

Untuk mencari solusi dari permasalahan diatas, berbagai konsep telah diajukan oleh para ilmuan dibidang akuntansi. Salah satunya adalah value added concept of income yang bernuansa sosial. Selanjutnya muncul kajian-kajian baru dalam bidang akuntansi seperti akuntansi sumber daya manusia, akuntansi lingkungan, dll.

Konsep value added concept of income telah lama dikenal dalam penilitian akuntansi sebagai salah satu alternatif penyajian laba. Berbeda dengan konsep laba, konsep nilai tambah tidak hanya difokuskan pada ekuitasmodal tetapi mengarah pada kepentingan lebih luas dalam bentuk distribusi pada seluruh stakeholders.

Di dalam sistem ekonomi Islam, terutama yang berkaitan dengan pola kerja sama usaha dalam bentuk syirkah, diatur tentang bagaimana hasil usaha (laba bersih) perusahaan didistribusikan kepada pihak-pihak yang bekerja. Permasalahan distribusi ini telah diatur oleh hukum-hukum Islam yang berkaitan dengan masalah kepemilikan, perolehan harta, pengelolaan harta, pengembangan harta, mata uang, jual beli dan distribusi kekayaan. Pendistribusian laba yang ditujukan dalam perbankan syariah yaitu distribusi laba untuk pemilik dana, distribusi laba untuk zakat, distribusi laba untuk karyawan, dan laba ditahan.

Islam mendorong umatnya untuk berjuang mendapatkan materi/harta dengan berbagai cara, asalkan mengikuti rambu-rambu yang telah ditetapkan. Rambu-rambu tersebut diantaranya: carilah yang halal lagi baik, tidak menggunakan cara batil, tidak berlebihlebihan/melampaui batas, tidak dizalimi maupun menzalimi, menjauhkan diri dari unsur riba, maisir (perjudian dan intended speculation), dan gahar (ketidak jelasan dan manipulatif), serta tidak melupakan tanggung jawab sosial berupa zakat, infak, dan sedekah. Ini yang membedakan sistem ekonomi Islam dengan perekonomian konvensional yang menggunakan prinsip self interest (kepentingan pribadi) sebagai dasar perumusan konsepnya.

\section{TINJAUAN PUSTAKA}

Laba merupakan suatu pos dasar dan penting dalam laporan keuangan yang memiliki berbagai kegunaan dalam berbagai konteks. Laba pada umumnya dipandang sebagai suatu dasar bagi perpajakan, penentuan kebijakan pembayaran dividen, pedoman investasi dan pengambilan keputusan dan unsur prediksi kinerja perusahaan (surepno, 2017).

Islam memandang bahwa laba bukanlah tujuan yang paling utama dalam pendirian suatu perusahaan atau organisasi. Tetapi bukan berarti perusahaan tersebut tidak boleh mendapatkan laba, hanya saja laba yang diperoleh harus halal dan sesuai dengan prinsip syariah Islam. Ada dua konsep Islam yang sangat berkaitan dengan 
pembahasan masalah laba, yaitu adanya mekanisme pembayaran zakat dan sistem tanpa bunga (Triyuwono, 2001)

Laba akuntansi perlu
diinterpretasikan lebih jauh hingga sampai pada mengintepetasikan laba akuntansi dari teks atau ayat-ayat $\mathrm{Al}$ Qur'an yang berkaitan dengan muamalah. Intepretasi di sini dilakukan untuk menggali konvensi dan aturan logis yang harus dipenuhi dalam bermuamalah (Ekasari:2014)

Mengenai pendapat di atas, maka konsep teoritis yang mampu memberikan dasar dalam pembentukan prinsip dan teknik akuntansi yang menghasilkan bentuk akuntabilitas dan informasi yang dibutuhkan oleh stockholders adalah enterprise theory. Hal ini demikian karena enterprise theory.

Enterprise theory menjelaskan bahwa akuntansi harus melayani bukan saja pemilik perusahaan, tetapi juga masyarakat. Triyuwono (2015) juga mengungkapkan akuntansi Syariah tidak saja sebagai bentuk akuntanbilitas (accountability) manajemen terhadap pemilik perusahaan (stockholders), tetapi juga sebagai akuntabilitas kepada stakeholders dan Tuhan.

Adapun bentuk keadilan yang harus ditegakkan menurut islam secara garis besar dapat diungkapkan sebagai: Keadilan dalam bentuk hubungan khaliq dan makhluq dan Keadilan dalam bentuk hubungan sesama makhluk.

\section{METODE PENELITIAN}

Metode penelitian yang digunakan adalah jenis deskriftif kualitatif yaitu analisis deskriptif dengan desain studi kasus. Dengan mendeskripsikan gambaran terhadap suatu objek. Penelitian deskriptif kualitatif adalah suatu penelitian yang dilakukan dengan tujuan utama untuk memberikan gambaran atau deskripsi tentang suatu keadaan secara objektif.

Lokasi dalam penelitian ini adalah PT. Bank Panin Dubai Syariah yang terdaftar di Bursa Efek Indonesia melalui situs-situs resmi (www.idx.co.id), Adapun sumber data yang digunakan dalam penelitian ini adalah Data sekunder yang diperoleh dari buku-buku, jurnal-jurnal, penelitian terdahulu serta literatur lain.

\section{HASIL DAN PEMBAHASAN}

\subsection{Hasil Penelitian}

PT Bank Panin Dubai Syariah Tbk merupakan salah satu perbankan syariah komersial terbesar di Indonesia dan telah terdaftar sahamnya di Bursa Efek Indonesia dan merupakan bagian dari Dubai Islamic Bank PJSC yang berkedudukan di Dubai UEA. Bank Panin Dubai Syariah berkomitmen untuk membangun kepercayaan nasabah dan masyarakat melalui pelayanan dan penawaran produk yang sesuai dengan prinsip-prinsip Syariah serta memenuhi kebutuhan nasabah.

Jumlah Saham yang dimiliki PT. Bank Panin Dubai Syariah Tbk sebesar 51,61\% tahun 2016, 44,69\% tahun 2017 dan 53,70\% tahun 2018. Dubai Islamic Bank PJSC sebesar 39,32\% tahun 2016, $38,25 \%$ tahun 2017 dan tetap sama sebesar 38,25\% untuk tahun 2018. dan masyarakat masing-masing dibawah 5\% yaitu sebesar 9,07\%. Tahun 2016, 17,06\% tahun 2017, dan 8,05\% tahun 2018.

Berdasarkan struktur kepemilikan saham yang dimliki PT. Bank Panin Dubai Syariah Tbk, kinerja keuangan perusahaan pertahun mengalami naik turun yaitu dapat dilihat dari laba bersih pada tahun 2016 yaitu sebesar Rp 
19.540.914.000, pada tahun 2017 mengalami kerugian sebesar Rp 968.851.297.000, dan pada tahun 2018 sudah kembali meningkat dengan laba sebesar Rp 20.788.229.000. dengan pencapaian kinerja keuangan PT. Bank Panin Dubai Syariah dari tahun 20162018 belum menunjukkan peningkatan yang signifikan, PT. Bank Panin Dubai Syariah terus berusaha untuk melakukan pemulihan untuk meningkatkan pendapatan dan kinerja perusahaan kedepan. Pendistribusian Laba pada PT. Bank Panin Dubai Syariah

\section{Pemegang Saham}

Saham Bank Panin Dubai Syariah yang terdaftar di Bursa Efek Indonesia dimiliki oleh beberapa badan dan sejumlah saham yang berbeda-beda Berdasarkan Rapat Umum Pemegang Saham Tahunan yang diselenggarakan pada tanggal 22 Mei 2017, perseroan tidak membagikan dividen kepada Para Pemegang Saham karena tidak mencapai kisaran laba bersih setelah pajak mulai dari 150 miliar sampai lebih 200 miliar.

Sedangkan pembagian laba kepada pera pemegang saham untuk tahun laba 2017, berdasarkan Rapat Umum Pemegang Saham tanggal 31 Mei 2018, dari Fathiah Helmi,S,.H notaris di Jakarta para pemegang saham setuju untuk menigkatkan modal perusahaan dari $\mathrm{Rp}$ 1.019.533.526.000 atau $\mathrm{Rp}$ 10.195.335.256 saham menjadi $\mathrm{Rp}$ 2.395.903.785.100 atau 23.959.037.851 saham. Modal ditempatkan dan disetor penuh adalah saham biasa yang memberikan hak satu suara per saham dan berpartisipasi dalam dividen.

\section{Nasabah}

Bank syariah berdasarkan pada prinsip profit and loss sharing (bagi untung dan bagi rugi). Bank syari'ah tidak membebankan bunga, melainkan mengajak partisipasi dalam bidang usaha yang didanai. Para deposan juga samasama mendapat bagian bagian dari keuntungan bank sesuai dengan rasio yang telah ditetapkan sebelumnya. Dengan demikian ada kemitraan antara bank syari'ah dengan para deposan di satu pihak dan antara bank dan para nasabah investasi sebagai pengelola sumber dana para deposan dalam berbagai usaha produktif di pihak lain.

PT. Bank Panin Dubai Syariah memeberikan hak pihak ketiga atas bagi hasil dana syirkah temporer sebesar Rp 480.604.374 dan mengalami penurunan tahun 2018 menjadi Rp 393.316.662. Turunnya besaran bagi hasil tersebut mencerminkan nasabah Bank panin Dubai Syariah menurun di tahun 2018. Penurunan ini disebabkan karena masalah kenaikan pembiayaan yang terjadi dari periode sebelumnya. Hal ini akan mempengaruhi tingkat kepercayaan nasabah pada pengelolaan dana Bank Panin Dubai Syariah. Akan tetapi Bank Panin Dubai Syariah terus memperbaiki dari permasalahan yang terjadi untuk meningkatkan kinerja perusahaan. Disisi lain, penyimpanan dana nasabah dalam perbankan syariah aman ditengah keadaan ekonomi yang tidak menentu karena dalam bank syariah menerapkan sistem bagi hasil sesuai dengan fatwa Dewan Syariah Nasional dan Dewan Pengawas Syariah.

\section{Distribusi Laba untuk Zakat}

Untuk perusahaan, zakat didasarkan pada prinsip keadilan serta hasil ijtihad para fuqaha. Salah satu prinsip akuntansi yang diapakai dalam system perhitungan zakat adalah konsep entitas. Dalam konsep ini perusahaan dianggap seorang wajib zakat, terpisah 
dengan kewajiban zakat dari para pemilik maupun pengelolanya. Konsep entitas ini juga diatur alam hokum islam, dalam firman Allah SWT terdapat pada surah At-Taubah ayat 103 yang artinya: Ambillah zakat dari sebagian harta mereka, dengan zakat itu kamu membersihkan dan mensucikan mereka dan mendoalah untuk mereka. Sesungguhnya doa kamu itu (menjadi) ketenteraman jiwa bagi mereka. dan Allah Maha mendengar lagi Maha Mengetahui.

Mengenai nizab dan presentase zakat, Surepno (2017) menyatakan bahwa nisab zakat perusahaan yaitu senilai 85 gram emas sedangkan persentasenya adalah 2,5\% dari aset wajib zakat yang dimiliki perusahaan selama masa haul. Bank Panin Dubai Syariah menghitung zakat perusahaan sebesar 2,5\% dari laba perseroan setelah pajak (laba dihitung menurut prinsip akuntansi) yang berlaku. pada tahun 2016, Bank Panin Dubai Syariah telah menyalurkan dana zakat karyawan, dana zakat nasabah dari tabungan dan deposito, serta infaq dan sedekah karyawan dan nasabah yang diterima oleh Bank Panin Dubai Syariah.

Distribusi nilai ekonomi terhadap pembayaran zakat, untuk laba tahun 2016, Panin Dubai Syariah Bank mengeluarkan Zakat sebesar $\mathrm{Rp}$ 711.570.000, melebihi aturan yang ditetapkan sebesar 2,5\% dari laba bersih yang seharusnya sebesar Rp 488.522.850 .Sedangkan untuk laba tahun 2017, Bank Panin Dubai Syariah tidak mengeluarkan Zakat karena mengalami kerugian. Dan untuk tahun 2018 juga tidak mengeluarkan zakat.

\section{Distribusi Laba untuk karyawan}

Karyawan merupakan salah satu faktor utama untuk menciptakan laba. Keberadaan tenaga kerja tidak boleh begitu saja dikesampingkan yang harus diperhatikan kesehatan dan kesejahteraannya. Hal yang tidak bisa lepas begitu saja dari tenaga kerja adalah upah. Penentuan upah merupakan salah satu penentu efisien atau tidaknya kerja seorang tenaga kerja.

Rasio pemberian gaji berbeda antar karyawan. Hal ini dinilai berdasarkan jenjang karir, tingkat pendidikan, dan pengalaman. Biaya gaji yang dikeluarkan PT. Bank Panin Dubai Syariah pada tahun 2018 adalah sebesar Rp 120.059.000 dan tahun 2017 sebesar Rp 144.316.000. Bank Panin Dubai Syariah senantiasa berupaya memaksimalkan penggunaan anggaran yang dialokasikan untuk pelatihan dan pendidikan karyawan sehingga mencapai hasil secara efektif. Total biaya untuk pelatihan karyawan pada tahun 2018 tercatat sebesar 5.841.287.000 dari total biaya tenaga kerja pada tahun tersebut, dibandingkan dengan Rp 469.042.000 yang dikeluarkan pada tahun 2017. Dan adanya penambahan biaya training dari tahun 2017 sebesar Rp 2,1 miliar atau kurang lebih 1,98\% dari total biaya tenaga kerja dan meningkat meningkat menjadi Rp 5,8 miliar atau kurang lebih $5,8 \%$ dari total biaya tenaga kerja tahun 2018. Ini mencerminkan bahwa perusahaan perhatian terhadap karyawanya.

Selama tiga tahun berakhir tingkat proyeksi kenaikan gaji pertahun yaitu 5,5\% tahun 2016, 5,50\% tahun 2017, dan tetap sama 5,50\% pada tahun 2018 . Hal ini membuktikan sistem pengembangan karyawan lebih terencana sesuai dengan kebutuhan 
bisnis dan organisasi, sehingga meminimalisir perpindahan dan mobilisasi dalam lingkungan perusahaan, serta dapat menjadi salah satu indikasi membaiknya tingkat keterlibatan karyawan (employee engagement) di Bank Panin Dubai Syariah.

Bank juga memberikan imbalan pasca kerja berupa iuran pasti dan imbalan pasti. Iuran pasti berasal dari $2 \%$ dari gaji pokok dan emolumen yang dibayarkan karyawan, sedangkan sisanya sebesar $2 \%$ sampai $7 \%$ diabayarkan oleh Bank per bulan. Imbalan pasca kerja manfaat pasti untuk karyawan sesuai dengan Undang-undang Ketenagakerjaan No. 13/2003. Perhitungan imbalan pasca kerja menggunakan metode Projected Unit Credit dengan penilaian akturia yang dilakukan pada setiap akhir periode pelaporan tahunan. Jumlah karyawan yang berhak memperoleh manfaat tersebut sebanyak 441 dan 736 karyawan masing-masing untuk tahun 2018 dan 2017.

\section{Distribusi Laba untuk Cadangan Umum}

Cadangan umum dipergunakan untuk menutup kerugian yang mungkin terjadi terhadap modal bank. Bank perlu memupuk cadangan umum untuk memperbesar jaminan terhadap kewajibannya dalam melakukan tugas dan usahanya. Cadangan umum juga berfungsi untuk menjamin kelangsungan usaha bank. Bank Indonesia mengatur tentang besar cadangan umum bank pada Peraturan Bank Indonesia Nomor: 10/15/Pbi/2008 Tentang Kewajiban Penyediaan Modal Minimum Bank Umum.

PT. Bank Panin Dubai Syariah menyisihkan sebagian laba bersih tahun
2016 sebesar Rp 10.715.676.000 ke akun cadangan umum. Rapat Umum Pemegang Saham tahunan yang diselenggarakan pada tanggal 31 Mei 2018 tidak ada saldo yang disisihkan dari sebagian laba bersih untuk tahun 2017 ke akun cadangan umum. Untuk laba tahun 2018, akan diputuskan dalam Rapat Umum Pemegang Saham yang dilakukan pada tahun 2019 dan akan dilaporkan pada Annual Report Bank Panin Dubai Syariah.

\section{Keadilan dalam Pendistribusian Laba}

Bank Panin Dubai Syariah sebagai bank murni syariah tidak menganut sistem bunga yang menjadi unsur riba dalam perbankan. Bank Panin Dubai Syariah menggunakan sistem bagi hasil sebagai bentuk pendistribusian keuntungan kepada para nasabah. Besarnya bagi hasil berdasarkan pada jumlah keuntungan yang diperoleh. Bila usaha merugi, kerugian akan dtanggung bersama oleh kedua belah pihak. Hal ini akan dinilai lebih adil disbanding sistem bunga yang memberikan tambahan pada pokok uang yang disimpan atau dipinjamkan tanpa memperitungakan untung rugi yang mengelola dana.

Pendistribusian laba dalam Bank Panin Dubai Syariah juga menghindari unzur kezaliman yaitu unsur yang merugikan diri sendiri, orang lain, maupun lingkungan. Para karyawan diberikan upah dan bonus yang senantiasa meningkat seiring dengan peningkatan laba perusahaan. Karir karyawan senantiasa diperhatikan dengan memberikan pelatihan untuk meningkatkan skill para karyawan. Dibidang lingkungan sekitar, Bank Panin Dubai Syariah menggunakan Zakat perusahaan, karyawan, dan nasabah untuk kegiatan-kegiatan sosial. Laba juga 
didistribusikan untuk dana cadangan umum yang berguna untuk menjaga kelangsungan perusahaan,

Dalam hal Gharar, Bank Panin Dubai Syariah bersikap terbuka kepada para stakeholdernya. Sebelum menandatangani akad, akan dijelaskan mengenai hak dan kewajiban bank dan para nasabah. Bank Panin Dubai Syariah menerbitkan Annual Report tiap tahunnya yang berisikan tentang laporan kinerja Bank Panin Dubai Syariah baik keuangan maupun non keuangan. Sehingga para pemegang saham dapat mengetahui besar keuntungan yang diperoleh, serta distribusi zakat dapat diketahui.

\subsection{Pembahasan}

\section{Distribusi Laba Akuntansi untuk Pemilik Dana}

Distribusi laba pada Bank Panin Dubai Syariah kepada pemegang saham dan nasabah. Pembagian laba kepada pemegang saham disesuaikan dengan jumlah saham yang dimiliki dengan mengalikan kepada 12\% nisbah bagi hasil sesuai kebijakan manajemen. Syarat pembagian laba nisbah bagi hasil nasabah tergantung kepada manfaat dan fasilitas yang diperoleh dari jasa atau produk yang diimiliki, dimana nisbah bagi hasil bervariasi mulai dari $0,5-1 \%$, bahkan dapat mencapai $69 \%$ jika dana melebihi > Rp 1000.000.000. jadi distribusi laba lebih besar kepada pemegang saham dibanding nasabah kecuali yang dananya diatas $\mathrm{Rp}$ 1.000.000.000. Jadi pendistribusian laba belum sepenuhnya terwujud keadilan karena melihat posisi pemegang saham masih lebih besar. Hasil penelitian mendukung hasil penelitian Ma'rifatun dkk (2015) yang meneliti pendistribusian laba akuntansi bukan hany kepada pemilik modal tetapi juga kepada stakeholder. Surepno (2017) hasil penelitiannya juga menunjukkan bahwa pendistribusian laba akuntansi didistribusikan kepada pemilik modal dan para stakeholder. Eka Okvyanti (2018) hasil penelitiannya juga menunjukkan bahwa pendistribusian laba pada BPR Adiartha Reksacitra yang menerapkan akuntansi konvensional, laba hanya didistribusikan kepada pemegang saham saja. Sedangkan pada BPRS Mitra Harmoni Blimbing yang menerapkan akuntansi syariah, distribusi laba tidak hanya kepada pemegang saham saja tetapi kepada pihak-pihak lainnya seperti nasabah, karyawan, pemerintah, dan masyarakat.

\section{Distribusi Laba Untuk Zakat}

PT. Bank Panin Dubai Syariah sudah mendistribusikan zakat walaupun hanya pada tahun 2016, tepatnya tahun 20172018 tidak ada didistribusikan zakat. Yang seharusnya walaupun kondisi keuangan perusahaan ditahun 2017 mengalami kerugian dan tahun 2018 belum stabil tetap membayar zakat. Penelitian ini dengan penelitian Monita Yuda Liantara (2018) yang menyatakan berbeda pendistribusian laba akuntansi lebih adil jika mendistribusikan zakatnya.

\section{Distribusi Laba untuk Karyawan}

Berdasarkan kebijakan yang diterapkan oleh PT. Bank Panin Dubai Syariah, telah adil dalam mendistribusikan laba terhadap karyawanya dilihat dari proyeksi kenaikan gaji pertahun dari 2016-2018 terus meningkat. walaupun pada tahun 2017-2018 jumlah presentasenya sama disebabkan mengalami keuangan yang tidak stabil.. Hal itu juga dilihat dari perhatian Bank Panin Dubai Syariah 
terhadap karyawanya yang telah mengeluarkan biaya pelatihan yang terus meningkat tiap tahunnya, Bank juga telah mengeluarkan imbalan pasca kerja manfaat. Hasil penelitian ini didukung oleh hasil penlitian Eva Okvyanti (2018) hasil penelitiannya bahwa distribusi laba tidak hanya kepada pemgang saham yang mendapati saja tetapi juga kepada nasabah, karyawan, pemerintah dan masyarakat.

\section{Distribusi Laba untuk Cadangan Umum}

Untuk cadangan umum PT. Bank Panin Dubai Syariah sudah menyisihkan sebagian laba bersihnnya pada tahun 2016. Sementara untuk tahun 2017-2018 tidak ada distribusi laba untuk cadangan umum yang disisihkan karena pada tahun 2017 Bank Panin Dubai Syariah mengalami kerugian. Bank Panin Dubai Syariah telah adil dalam penyisihan laba untuk cadangan umum karena mengalokasikan dana cadangan umum ketika kondisi keuangan perusahaan memperoleh laba.

Pada penelitian terdahulu tidak ada yang meneliti mengenai distribusi laba untuk cadangan umum, sehingga hasil penelitian dapat mengisi dan menambah kekurangan dalam literatur khususnya pendistribusian laba dalam akuntansi syariah.

\section{PENUTUP}

\subsection{Simpulan}

Dari hasil penelitian penulis dapat menyimpulakan bahwa pendistribusian laba pada PT. Bank Panin Dubai Syariah telah menerapkan prinsip Syariah. Laba yang dihasilkan oleh perusahaan bukanlah didistribusikan untuk pemilik modal saja akan tetapi didistribusikan untuk nasabah dalam bentuk nisbah bagi hasil, mengeluarkan zakat perusahaan walaupun dalam keadaan tidak memperoleh laba dan bonus bagi karyawan berdasarkan nilai laba yang diperleh setiap tahuannya. Serta mengaloaksikan untuk cadangan umum sebagai proteksi dan untuk menjaga keberlangsungan perusahaan.

\subsection{Saran}

Bank Panin Dubai Syariah hendaknya lebih transparan dalam pengelolaan zakat karena dana kebajikan bisa dipisahkan antara zakat perusahaan dan zakat nasabah.

\section{DAFTAR PUSTAKA}

Al-Qur'an dan Terjemahannya 2014.

Aprianti, H.W. 2017. Akuntansi Syariah: Sebuah Tinjauan Antara Teori dan Praktik. Jurnal Akuntansi Indonesia. Vol. 6 No 2

Belkaouli, Ahmed. 2011. Teori Akuntansi. (terj. Dukat, Erwan, et. al.). Jakarta: Penerbit Erlangga.

Ekasari,Kurnia. 2014: Hermeneutika laba dalam persfektif Islam.Jurnal Akuntansi Multiparadigma.Vol.5 No.1

Harahap et al. 2010. Akuntansi Perbankan Syariah.Jakarta: LPFE Usakti.

Harahap, S.S. 2010. Beberapa Dimensi Akuntansi: Menurut Al-Qur'an, Ilahiyah, Sejarah Islam dan Kini. Media Riset Akuntansi, Auditing dan Informasi. Vol. 2 No. 2,

Ikatan Akuntan Indonesia. 2017. Standar Akuntansi Keuangan Syariah. Jakarta: Ikatan Akuntan Indonesia.

Ma'rifatun, et al. 2015. Analisis Sistem Penerapan Bagi Hasil terhadap Perolehan Laba Berdasarkan Prinsip Syari'ah. jurnal akuntansi. Vol. 2 No. No. 3 ,

Muhammad. 2010. Manajemen Bank Syari'ah. Yogyakarta: UPP AMP YKPN.

Nurhayati, S., dan Wasilah. 2014. Akuntansi Syariah di Indonesia. Jakarta: Salemba Empat. 
Resmi, Siti. 2012. Perpajakan Teori dan Kasus. Jakarta: Salemba Empat.

Srisusilawati, P., dan Eprianti, N. 2017. Penerapan Prinsip Keadilan Dalam Akad Mudhrabah Di Lembaga Keuangan Syariah. Jurnal Law and Justice. Vol. 2 No. 1

Surepno, dan Jayanto,P.Y. 2017. Distribusi Laba Sebagai Implementasi Nilai Keadilan Dalam Akuntansi Syariah Pada PT. Bank Syariah Mandiri. Jurnal Ekonomi Syariah.Vol. 5 No. 1,.

Suwardjono. 2014. Teori Akuntansi Perekayasaan Pelaporan Keuangan Edisi Ketiga. Yogyakarta: BPEYogyakarta.

Syihab, Muhammad Baiquni. 2012. Reformasi Akuntansi Syariah: Rancang
Bangun Laporan Keuangan Neraca Berbasis Syirkah Islam. Akuntansi. Vol. 2 Nomor 3,

Triwono,iwan. 2015. Akuntansi Syariah: Perspektif, metodoogi, dan Teori Ed.2Cet.4. Jakarta: Rajawali Pers.

Vahid, Navid, et al. 2013. Comparison Between Accounting Profit and Economic Profit and its Effect on Optimal Point of Production, Jurnal of Natural and Social Science. Vol. 2. No. 3,

Wibowo, dan Arif, A. 2009. Akuntansi Keuangan Dasar 2. Jakarta: Grasindo. https://www.idx.co.id/https://www. paninbanksyariah.co.id/ 